\title{
JOB SATISFACTION LEVELS OF PRIMARY HEALTH CARE NURSES AND MIDWIVES WORKING IN THE DISTRICTS OF ADAPAZARI, SERDIVAN AND ERENLER IN SAKARYA ${ }^{1}$
}

\section{SAKARYA İLINE BAĞLI ADAPAZARI, SERDIVAN, ERENLER ILÇELERINDE BİRINCI BASAMAK SAĞLIK HIZMMETLERINDE ÇALIŞAN HEMŞİRE VE EBELERIN MESLEKI DOYUMLARI}

\author{
Hamide ZENGIN ${ }^{1}$, Ayşe ÇEVIRME ${ }^{2}$, Özge ERTÜRK ${ }^{3}$ \\ ${ }^{1}$ Sakarya University, Institute of Health Sciences, Sakarya / Turkey \\ ${ }^{2-3}$ Sakarya University, Faculty of Health Sciences, Nursing Department, Sakarya / Turkey
}

ORCID ID: 0000-0002-2389-6466 ${ }^{1}, 0000-0001-7116-2523^{2}, 0000-0001-9238-490 X^{3}$

Öz: Amaç: Bu çalışma, birinci basamak sağlık hizmetlerinde hemşire, ebe ve Aile Sağlığı Elemanı (ASE) olarak çalışan sağlık personellerinin mesleki doyumları ve etkileyen faktörlerini belirlemek ve bazı değişkenler açısından incelemek amacı ile yapıldı. Yöntem: Tanımlayıcı ve analitik tipteki araştırmanın örneklemini üç Toplum Sağlığı Merkezi (TSM) ve 41 Aile Sağlığı Merkezinde (ASM) çalışan araştırmaya katılmayı kabul eden 100 hemșire, ebe ve ASE'ler olușturdu. Veriler, "Soru Formu" ve "Minnesota İș Doyum Ölçeği" kullanılarak toplandı. Verilerin değerlendirilmesinde sayı, yüzdelik, ortalama, Kruskall Wallis Testi, Mann-Whitney U Testi, Independent t Testi, One-Way ANOVA ve Pearson Korelasyon Katsayısı kullanıldı. Bulgular: Katılımcıların \%52,5'inin TSM'de çalıștı̆̆ $\% 47,5$ 'inin ASM'de çalışmaktadır. Genel iş doyumu "yeterli" düzey olarak saptanmıştır. Genel iş doyumu puanı bakımından birinci basamakta çalışılan yerler arasında istatistiksel olarak anlamlı bir farklılık bulunduğu $(\mathrm{p}<0,05)$ ASM'de çalışanların genel iş doyumu puanı TSM'de çalışanlara göre anlamlı derecede yüksek olduğu saptandı. ASM'de çalışanların dış faktörler puanı TSM'de çalışanlara göre anlamlı derecede yüksek olduğu belirlendi. Yaş değerleri ve hizmet süresi arttıkça genel is doyumu, iç faktörler puanı ve dıs faktörler puanı azaldığı belirlendi. Sonuç: Bu çalışmada, mesleği isteyerek seçmenin iş doyumu üzerinde olumlu etkisinin olduğunu; bu faktörü gidermek için meslek seçiminden önce öğrencilere meslek ile ilgili bilgilendirmelerin yapılmasını, halen aktif olarak çalıșan meslektașlarımıza hizmet içi eğitimlerin yapılması, görev tanımın uygulanması, personel eksikliği, fiziki şartların düzenlenmesi gerektiği sonucuna ulaşıldı.

Anahtar Kelimeler: Aile Sağlığı Elemanı, Birinci Basamak Sağlık Hizmetleri, Ebe, Hemşire, İş Doyumu
Abstract: Purpose:This study was conducted in order to determine the professional satisfaction of nurses, midwives and Family Health Staff(FHS) working in Primary Health Care Services and to evaluate the related factors in terms of some variables. Method: Being a descriptive and an analytical one, this research had a sample of 100 voluntary nurses, midwives and FHS working in three different Public Health Center(PHC) and 41 Family Health Center(FHC). Data were collected via a "questionnaire" and "Minnesota Satisfaction Questionnaire(MSQ)". For the evaluation of the data, number, percentage, mean, Kruskal-Wallis test, Mann-Whitney $\mathrm{U}$ test, Independent t-test, One-Way ANOVA and Pearson correlation coefficient were used. Results: A total of $52.5 \%$ worked in PHC and 47.5\% worked in FHC. Job satisfaction in general was found as "sufficient" level. As for the scores of job satisfaction in general, there was a statistically significant difference among the places they worked $(p<0,05)$; the people who worked in FHCs had a significantly higher score of job satisfaction in general compared to the ones who worked in PHCs. It was seen that as the age and total working period increased, general job satisfaction, internal and external factor scores decreased. Conclusion: It was concluded in this study that choosing a job willingly had a positive effect on job satisfaction. It should be better to inform the students on this issue before they choose a job, recent staff should be given the opportunity of in-service training as much as possible, job definitions should be made, and lack of staff and insufficient physical conditions should be remedied.

Key Words: Family Health Staff, Job Satisfaction, Midwife, Nurse, Primary Health Care Services

Doi: 10.17363/SSTB.2017.2.03

(1) Corresponding Author: Ayşe ÇEVIRME, Sakarya University, Institute of Health Sciences, Sakarya / Turkey, acevirme@sakarya.edu.tr, Received: 27.01.2017, Accepted: 19.06.2017, Type ofarticle (Research-Application) Conflict of Interest: None / "None of Ethics Committee" 


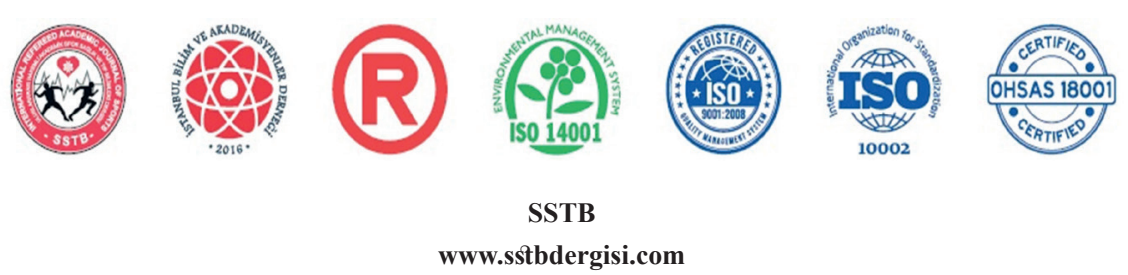

International Refereed Academic Journal of Sports, Health and Medical Sciences

April - May - June Issue 23 Winter Season Year: 2017

JEL CODE: I10-I11-M10-M12 ID:342 K:231

ISSN Print: 2146-8508 Online 2147-1711

(ISO 18001-OH-0090-13001706 / ISO 14001-EM-0090-13001706 / ISO 9001-QM-0090-13001706 / ISO 10002-CM-0090-13001706) (TRADEMARK)

(2015/04315- 2015-GE-18972)

\section{INTRODUCTION}

Job satisfaction is described as the level of physical, mental and social satisfaction or the emotional reactions of the employee upon an evaluation of his job and his business environment (Duxbury, 1984: 97-101; Durmus, 2007: 139-146; Kahraman, 2011: 12-18). The most important aspect of employee success, comfort and productivity is job satisfaction (Duxbury, 1984: 97-101; Aytekin, 2014: 51-58; Durmus, 2007: 139-146). Factors affecting job satisfaction are personal factors and organizational factors. Age, gender, educational status, marital status, occupational status, length of service, socio-cultural environment and personality traits are individual factors and the job done and its nature, management and control, fees, promotion opportunities, the physical conditions and social environment of the workplace are organizational or environmental factors (Aksu, 2002: 271-282; Asegid, 2014; Aytekin, 2014: 51-58; Cetin, 2013: 145-163; Erbil, 2004: 3; Kaya and Bilgin, 2015: 1).

Job satisfaction is essential in any job. Factors such as severe working conditions, low pay, and lack of respect for the profession can lead to poor job satisfaction among nurses and midwives in health care (Durmus, 2007: 139-146).
While job satisfaction of nurses and midwives and Family Health Staff (FHS) working in preventive health services leads to physical, social and mental well-being, a high quality of care and a high level of community health (Aydin and Akan, 2010: 1; Hampton, 2012: 2; Senbounsou, 2013: 233-241; Kaya and Bilgin, 2015: 1), a low level of job satisfaction or dissatisfaction results in a deceleration in the work done, constant complaints, lack of concentration, thinking about leaving work and an increase in problems and errors related to business discipline (Tekin et al., 2014: 135139; Kaya and Bilgin, 2015: 1).

Organizations offering health care services, structured and among the most complex organizations in terms of function (Erat et al., 2011: 48-77). Quality and sufficiency in requested and given health services; It is the most prominent indicator of the socio-economic development level of that country (Korkmaz and Yilmaztürk, 2011: 77-96). In order to make health care services accessible and available to everyone, it is needed to reinforce primary health care services by ensuring high levels of job satisfaction among the staff (Tekin et al., 2014: 135-139).

Family Health Staff (FHS) in Family Health Centers (FHC) in our country have the duties and responsibilities of giving care and treatment, laboratory services, secretarial services, mobile health services, maternal and child 


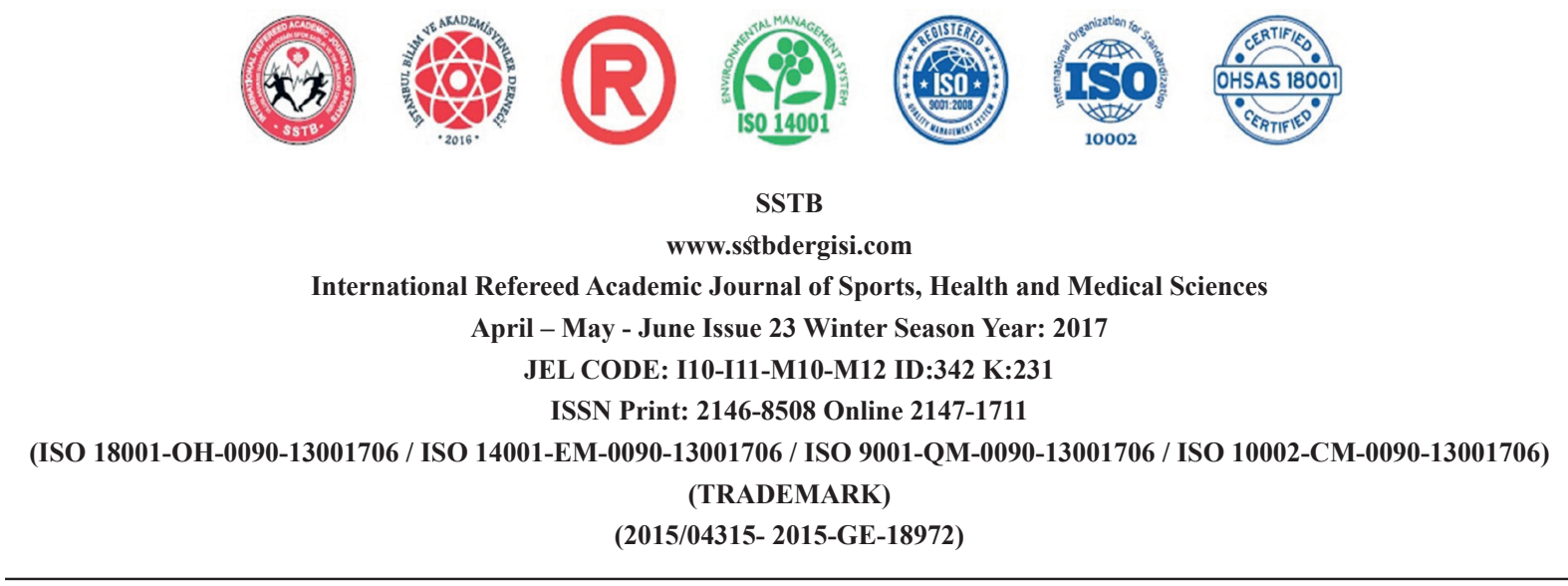

health, reproductive health, assisting family doctors in house visits, attending in-service training. Not every FHS do all these jobs. There are groups in FHCs such as A, B, C, D and $\mathrm{E}$ (out of classifications) determined by the Ministry of Health. In the groups of A, $\mathrm{B}, \mathrm{C}$ there should be a staff other than FHS, whereas there should be one more health staff for Group A FHCs. ${ }^{1}$

Nurses and midwives working in Public Health Centers have the duties and responsibilities such as records, statistics, control of infectious and non-infectious diseases, reproductive health services, national programs, forensic services, emergency medical services, prevention from accident and injuries, imaging and laboratory services, environmental health services, occupational health and safety services, disaster services, improving health and promoting health education services, public areas and school health services, social work services. ${ }^{2}$

There are a number of studies concerning the primary care nurses, midwives and FHS (Tekin et al., 2014: 135-

139; Erbil, 2004: 3; Kaya and Bilgin, 2015: 1, Doğan et al., 2013: 112-5). Our study dif-

1 http://ailehekimligi.gov.tr/component/content/ article/102-gorusler/2372-aile-hekimlii-uygulamayoenetmelii.html

2 http://ailehekimligi.gov.tr/toplum-sal-merkezi. html fers from the others in terms of focusing on the staff in both PHCs and FHCs together and also by considering various FHC groups. This study also fulfils a need to compare the job satisfaction of the staff working as nurses and midwives in PHCs and as FHS working in FHCs and also between FHSs working in different FHC groups.

\section{OBJECTIVE}

This study was performed as a descriptive and sectional one in order to detect job satisfaction levels and the affecting factors of health staff working as primary care nurses, midwives and Family Health Staff (FHS).

\section{MATERIAL and METHOD}

The population consisted of primary care nurses, midwives and FHS ( $\mathrm{n}=1059)$ working in 16 PHCs and 94 FHCs in Sakarya. The data were collected in 2016 from three Public Health Centers (PHC) and fourty-one Family Health Centers (FHC) in three districts of Sakarya. FHCs were chosen by using random number charts. To detect the number of samples, the item number of 20-item Minnesota Job Satisfaction Questionnaire (MSQ) were multiplied by five; sample number was found as 100 . The sample of the universe consisted of 100 nurses, midwives and FHS who volunteered to participate in the study. The data from a participant who did not complete the form was omitted and the data from 99 partic- 


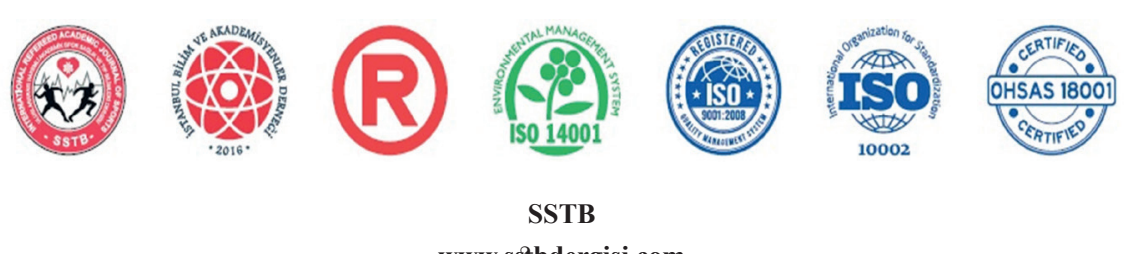

Www.sstbdergisi.com

International Refereed Academic Journal of Sports, Health and Medical Sciences

April - May - June Issue 23 Winter Season Year: 2017

JEL CODE: I10-I11-M10-M12 ID:342 K:231

ISSN Print: 2146-8508 Online 2147-1711

(ISO 18001-OH-0090-13001706 / ISO 14001-EM-0090-13001706 / ISO 9001-QM-0090-13001706 / ISO 10002-CM-0090-13001706) (TRADEMARK)

(2015/04315- 2015-GE-18972)

ipants were evaluated. The nurses, midwives and FHS who volunteered, had no communication problems and worked actively were included in the study.

\section{Data Collection Tools}

A questionnaire, consisting of two parts, was used in order to detect the job satisfaction levels of participants and also face-toface sessions were included. In the first part, an identifying information form of 13 items which aimed to determine the personal, socio-demographic and occupational features of nurses, midwives and FHS. In the second part, a 20-item Likert type Minnesota Job Satisfaction Questionnaire (MSQ) was used to find out about the job satisfaction levels. The most widely used job satisfaction scale MSQ, which was developed by Weiss, Dawis, England and Lofquist, has two types; the longer type consists of 100 items, and the shorter one has 20 items. The longer type has two versions; one is 1967 and the other is

1977 (Mercanlığlu, 2012: 121-138; Baycan, 1985). The question form involves propositions to detect the satisfaction / dissatisfaction of employees on various dimensions of their jobs. It was translated into Turkish, its validity- reliability studies were performed by A.F. Baycan from Boğaziçi University in 1985. Baycan tested the scale he had adapted in four different areas including health sector
(Baycan, 1985). MSQ can detect the internal (12 items) and external (8 items) satisfaction factors and it's designed as Likert type scoring. The questionnaire consists of 20 items ranging from 1 to 5 expressing "strongly dissatisfied", "dissatisfied", "no opinion", "satisfied", "strongly satisfied". For the evaluation of the scale, the total score from the items is divided by 20 in order to find the general satisfaction score (Derin, 2007). The highest score is 100 , the lowest is 20 . Scores between 20-39 are "very low", 40-59 are "low", 60-79 are "sufficient", 80-100 are "high" levels of satisfaction.

\section{Evaluation of Data}

Data collected were evaluated by SPSS 20 on computer. Shapiro Wilk's was used to search for the availability of variables to the normal distribution. While evaluating the results, the level of significance was given as 0,05 ; when $p<0,05$, variables are out of normal distribution and when $p>0,05$, the variables are of normal distribution. Independent $t$ Test and One-Way ANOVA are used when evaluating the differences between the groups. When there were significant differences in One-Way ANOVA and the groups had homogenous variances, Tukey HSD was used. When the variances were not homogenous, Tamhane's Analysis was used. When analyzing the differences between the groups if the variables are out of normal distribution 


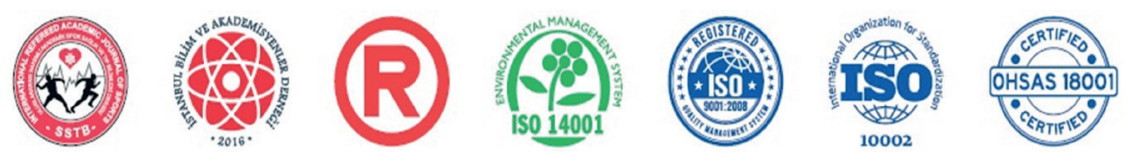

SSTB

www.sstbdergisi.com

International Refereed Academic Journal of Sports, Health and Medical Sciences

April - May - June Issue 23 Winter Season Year: 2017

JEL CODE: I10-I11-M10-M12 ID:342 K:231

ISSN Print: 2146-8508 Online 2147-1711

(ISO 18001-OH-0090-13001706 / ISO 14001-EM-0090-13001706 / ISO 9001-QM-0090-13001706 / ISO 10002-CM-0090-13001706)

(TRADEMARK)

(2015/04315- 2015-GE-18972)

Mann Whitney U and Kruskal Wallis-H tests were used. Since number of units are more than 20, standardized $\mathrm{z}$ values were given for Mann Whitney U test. When there were significant differences in Kruskal Wallis_H test, Post-Hoc comparison test was used in order to determine the groups with differences. When analyzing the correlation between the variables out of normal distribution, Spearman's Correlation Coefficient was used. For the evaluation of correlation between the variables confirming with the normal distribution, Pearson Correlation Coefficient was used. When assessing the results, significance level was taken as 0,05 ; if $p<0,05$ there was a significant correlation and if $p>0,05$ there was no significant correlation.

\section{Ethical Considerations}

After necessary consents were obtained for ethical considerations, nurses, midwives and FHS participating in the study were informed and the voluntary ones were included in the study. 
 \\ SSTB \\ www.sstbdergisi.com}

International Refereed Academic Journal of Sports, Health and Medical Sciences April - May - June Issue 23 Winter Season Year: 2017

JEL CODE: I10-I11-M10-M12 ID:342 K:231

ISSN Print: 2146-8508 Online 2147-1711

(ISO 18001-OH-0090-13001706 / ISO 14001-EM-0090-13001706 / ISO 9001-QM-0090-13001706 / ISO 10002-CM-0090-13001706) (TRADEMARK)

(2015/04315- 2015-GE-18972)

\section{RESULTS}

Table 1. The Distribution of Participants According to Personal Information

The average age of the participants was 35,99 $\pm 8,31$ (the youngest $=19$, the oldest $=60$ ), the average working time was $15,44 \pm 8,76$ (the least $=6$ months, the most $=38$ years).

\begin{tabular}{|c|c|c|c|}
\hline Features & & $\mathbf{n}$ & $\%$ \\
\hline \multirow[t]{3}{*}{ Marital Status } & Single & 7 & 7,07 \\
\hline & Married & 88 & 88,89 \\
\hline & Widowed / Separated & 4 & 4,04 \\
\hline \multirow[t]{3}{*}{ Monthly income-expense } & Less income than expenses & 39 & 39,39 \\
\hline & Equal & 47 & 47,47 \\
\hline & More income than expenses & 13 & 13,13 \\
\hline \multirow[t]{4}{*}{ Level of education } & Health high school & 23 & 23,23 \\
\hline & Associate degree & 45 & 45,45 \\
\hline & License degree & 29 & 29,29 \\
\hline & Graduate degree/doctorate & 2 & 2,02 \\
\hline \multirow[t]{3}{*}{ Choosing the profession willingly } & Yes & 61 & 61,62 \\
\hline & No & 38 & 38,38 \\
\hline & Total & 99 & 100 \\
\hline \multirow[t]{3}{*}{ Working Unit } & Family Health Center & 47 & 47,47 \\
\hline & Public Health Center & 52 & 52,53 \\
\hline & Total & 99 & 100 \\
\hline \multirow[t]{5}{*}{ FHC type } & A & 25 & 53,19 \\
\hline & $\mathrm{C}$ & 5 & 10,64 \\
\hline & $\mathrm{D}$ & 10 & 21,28 \\
\hline & E & 7 & 14,89 \\
\hline & Total & 47 & 100 \\
\hline
\end{tabular}

A total of 47 out of 99 participants $(47,5 \%)$ who filled in the questionnaire were working in FHC, a total of 52 (52,5\%) were work- ing in PHC. Among the FHS, a total of 25 $(53,19 \%)$ were working in Group A, and 10 were working $(21,28 \%)$ in Group D. Since 


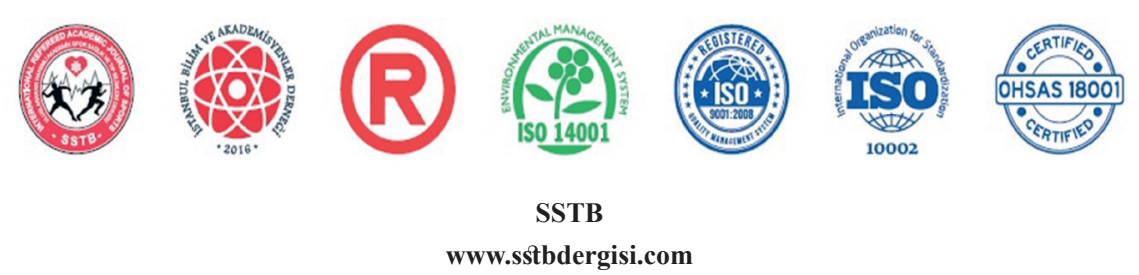

International Refereed Academic Journal of Sports, Health and Medical Sciences April - May - June Issue 23 Winter Season Year: 2017

JEL CODE: I10-I11-M10-M12 ID:342 K:231

ISSN Print: 2146-8508 Online 2147-1711

(ISO 18001-OH-0090-13001706 / ISO 14001-EM-0090-13001706 / ISO 9001-QM-0090-13001706 / ISO 10002-CM-0090-13001706) (TRADEMARK)

(2015/04315- 2015-GE-18972)

random sampling was used, Group B FHS were not included in our study. A total of 45 participants $(45,45 \%)$ were associate degree graduates, a total of $29(29,29 \%)$ were of license degree and 88 of them $(88,89 \%)$ were married. A total of $61(61,62 \%)$ participants chose their profession willingly and 47 of them $(47,47 \%)$ stated that their income and expenses were equal to each other.

There is no statistically significant correlation between marital status, monthly income and expense and educational status and general job satisfaction scale and its subscales $(\mathrm{p}>0,05)$.

Table 2. The Distribution of Participants According to the Average Scores of General Job Satisfaction Scale and Subscales Internal Factors and External Factors

\begin{tabular}{llll}
\hline Subscales & $\mathbf{X} \pm$ SS & Min & Max \\
\hline General Job satisfaction & $67,85 \pm 11,3$ & 34 & 95 \\
\hline Internal Factors & $41,89 \pm 6,91$ & 25 & 58 \\
\hline External Factors & $25,96 \pm 5,36$ & 9 & 38 \\
\hline
\end{tabular}

Table 2 shows the average scores of participants from the subscales of job satisfaction scale. Participants got an average score of $(41,89 \pm 6,91)$ from internal satisfaction sub- scale and an average score of $(25,96 \pm 5,36)$ from external subscale. Total average score from job satisfaction scale is $67,85 \pm 11,3$. 


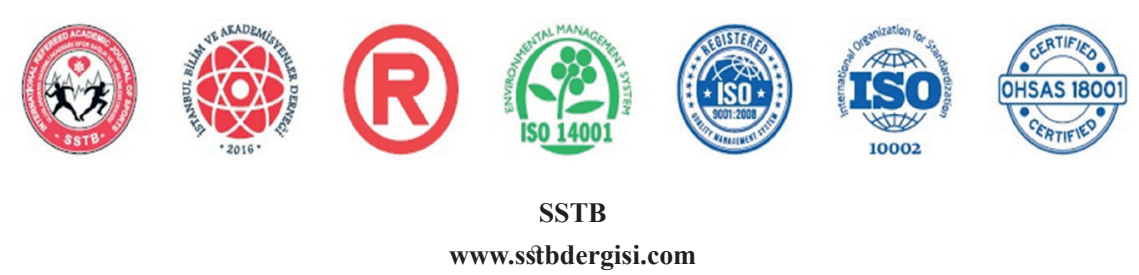

International Refereed Academic Journal of Sports, Health and Medical Sciences April - May - June Issue 23 Winter Season Year: 2017

JEL CODE: I10-I11-M10-M12 ID:342 K:231

ISSN Print: 2146-8508 Online 2147-1711

(ISO 18001-OH-0090-13001706 / ISO 14001-EM-0090-13001706 / ISO 9001-QM-0090-13001706 / ISO 10002-CM-0090-13001706) (TRADEMARK)

(2015/04315- 2015-GE-18972)

Table 3. The Average Scores of Participants from General Job Satisfaction Scale and Its Subscales According to Some Socio-Demographic Features

\begin{tabular}{|c|c|c|c|c|c|}
\hline & & \multicolumn{4}{|c|}{$\begin{array}{c}\text { The state of choosing the profession } \\
\text { willingly }\end{array}$} \\
\hline & & $\mathrm{n}$ & $\mathrm{X} \pm \mathrm{SS}$ & & $\mathrm{p}$ \\
\hline \multirow[t]{3}{*}{ General Job Satisfaction } & yes & 61 & $69,28 \pm$ & 9,77 & \multirow[t]{3}{*}{$0,138 *$} \\
\hline & no & 38 & $65,55 \pm$ & 13,21 & \\
\hline & Total & 99 & $67,85 \pm$ & 11,3 & \\
\hline \multirow[t]{3}{*}{ Internal Factors } & yes & 61 & $42,48 \pm$ & 5,83 & \multirow[t]{3}{*}{$0,328^{*}$} \\
\hline & no & 38 & $40,95 \pm$ & 8,36 & \\
\hline & Total & 99 & $41,89 \pm$ & 6,91 & \\
\hline \multirow[t]{3}{*}{ External Factors } & yes & 61 & $26,8 \pm$ & 4,86 & \multirow[t]{3}{*}{$0,044 * *$} \\
\hline & no & 38 & $24,61 \pm$ & 5,9 & \\
\hline & Total & 99 & $25,96 \pm$ & 5,36 & \\
\hline \multirow[t]{3}{*}{ General Job Satisfaction } & $\mathrm{FHC}$ & 47 & $70,6 \pm$ & 10,88 & \multirow[t]{3}{*}{$0,021 *$} \\
\hline & PHC & 52 & $65,37 \pm$ & 11,19 & \\
\hline & Total & 99 & $67,85 \pm$ & 11,3 & \\
\hline \multirow[t]{3}{*}{ Internal Factors } & FHC & 47 & $43,19 \pm$ & 6,82 & \multirow[t]{3}{*}{$0,056^{* *}$} \\
\hline & PHC & 52 & $40,71 \pm$ & 6,84 & \\
\hline & Total & 99 & $41,89 \pm$ & 6,91 & \\
\hline \multirow[t]{3}{*}{ External Factors } & FHC & 47 & $27,4 \pm$ & 5,22 & \multirow[t]{3}{*}{$0,008 * *$} \\
\hline & $\mathrm{PHC}$ & 52 & $24,65 \pm$ & 5,2 & \\
\hline & Total & 99 & $25,96 \pm$ & 5,36 & \\
\hline
\end{tabular}

* Independent t Test $\quad * *$ Mann Whitney U Test

There is no statistically significant difference between the status of choosing the profession willingly in terms of external factors score $(p<0,05)$. External factors score is significantly higher in the ones who chose the profession willingly when compared to the ones who did not. There is a statistically significant difference between the primary work places in terms of general job satisfaction $(p<0,05)$. General job satisfaction scores of the ones who work in FHCs are significantly higher than the ones who work in PHCs. In terms of external factors, there is a statisti- 


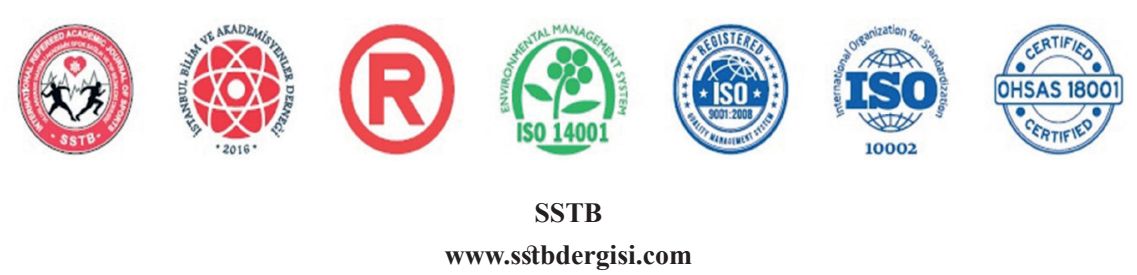

International Refereed Academic Journal of Sports, Health and Medical Sciences April - May - June Issue 23 Winter Season Year: 2017

JEL CODE: I10-I11-M10-M12 ID:342 K:231

ISSN Print: 2146-8508 Online 2147-1711

(ISO 18001-OH-0090-13001706 / ISO 14001-EM-0090-13001706 / ISO 9001-QM-0090-13001706 / ISO 10002-CM-0090-13001706) (TRADEMARK)

(2015/04315- 2015-GE-18972)

cally significant difference between the work places in the primary level $(p<0,05)$. External factor scores of the ones who work in FHCs are higher than the ones who work in PHCs (Table 3).

Table 4. Average Scores of Participants According to FHC Types; General Job Satisfaction Scale and Its Subscales

\begin{tabular}{|c|c|c|c|c|c|}
\hline & & \multicolumn{4}{|c|}{ The Type of FHC } \\
\hline & & $\mathrm{N}$ & & & $\mathrm{p}$ \\
\hline \multirow[t]{5}{*}{ General Job Satisfaction } & A & 25 & $68,36 \pm$ & 11,24 & \multirow[t]{4}{*}{$0,042 *$} \\
\hline & $\mathrm{C}$ & 5 & $74,2 \pm$ & 5,93 & \\
\hline & $\mathrm{D}$ & 10 & $67,6 \pm$ & 10,28 & \\
\hline & $\mathrm{E}$ & 7 & $80,29 \pm$ & 7,99 & \\
\hline & Total & 47 & $70,6 \pm$ & 10,88 & $1-4$ \\
\hline \multirow[t]{5}{*}{ Internal Factors } & A & 25 & $45 \pm$ & 6,88 & \multirow[t]{4}{*}{$0,018 * *$} \\
\hline & $\mathrm{C}$ & 5 & $44 \pm$ & 3,36 & \\
\hline & $\mathrm{D}$ & 10 & $39 \pm$ & 6,55 & \\
\hline & $\mathrm{E}$ & 7 & $49 \pm$ & 4,69 & \\
\hline & Total & 47 & $45 \pm$ & 6,82 & $1-4,3-4$ \\
\hline \multirow[t]{5}{*}{ External Factors } & A & 25 & $26,24 \pm$ & 5,67 & \multirow[t]{5}{*}{$0,236^{*}$} \\
\hline & $\mathrm{C}$ & 5 & $29,6 \pm$ & 3,05 & \\
\hline & $\mathrm{D}$ & 10 & $27,2 \pm$ & 4,85 & \\
\hline & $\mathrm{E}$ & 7 & $30,29 \pm$ & 4,42 & \\
\hline & Total & 47 & $27,4 \pm$ & 5,22 & \\
\hline
\end{tabular}

* One Way ANOVA, ** Kruskall Wallis H Test

In terms of general job satisfaction scores, there is a statistically significant difference between the types of FHCs $(p<0,05)$. The scores of general job satisfaction of the ones who work in E type FHCs are higher than the ones who work in A type FHCs. In terms of internal factor scores, there is a statistically significant difference between the types of FHCs $(p<0,05)$. E type FHC staff have higher internal factor scores than the ones who work in A type and D type FHC staff. In terms of external factors, there is no statistically significant difference between the types of FHCs ( $>0,05)$ (Table 4). 


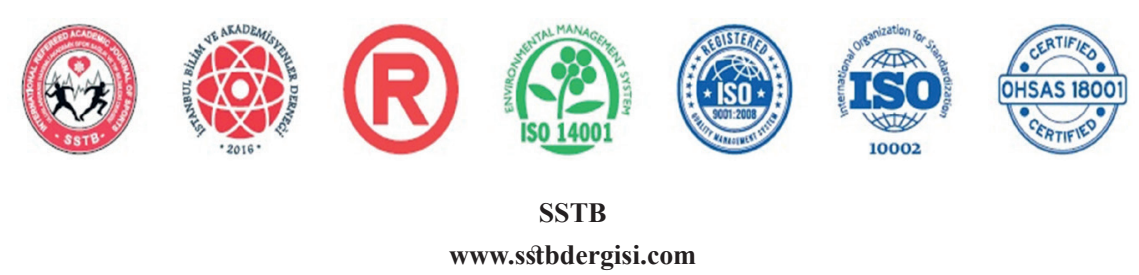

International Refereed Academic Journal of Sports, Health and Medical Sciences April - May - June Issue 23 Winter Season Year: 2017

JEL CODE: I10-I11-M10-M12 ID:342 K:231

ISSN Print: 2146-8508 Online 2147-1711

(ISO 18001-OH-0090-13001706 / ISO 14001-EM-0090-13001706 / ISO 9001-QM-0090-13001706 / ISO 10002-CM-0090-13001706) (TRADEMARK)

(2015/04315- 2015-GE-18972)

Table 5. The Correlation Between Age and Total Working Period and General Job Satisfaction Scale and Its Subscales

\begin{tabular}{lccc}
\hline & \multicolumn{2}{c}{ Age } & Total Working Period \\
\hline \multirow{2}{*}{ Total Working Period } & $\mathrm{r}$ & 0,956 & \\
\cline { 2 - 4 } & $\mathrm{p}$ & 0,001 \\
\cline { 2 - 4 } & $\mathrm{n}$ & 99 & \\
\hline General Job Satisfaction & $\mathrm{r}$ & $-0,113$ & $-0,102$ \\
\cline { 2 - 4 } & $\mathrm{p}$ & 0,267 & 0,313 \\
\cline { 2 - 4 } & $\mathrm{n}$ & 99 & 99 \\
\hline Internal Factors & $\mathrm{r}$ & $-0,075$ & $-0,068$ \\
\cline { 2 - 4 } & $\mathrm{p}$ & 0,462 & 0,505 \\
\hline & $\mathrm{n}$ & 99 & 99 \\
\hline External Factors & $\mathrm{r}$ & $-0,122$ & $-0,101$ \\
\cline { 2 - 4 } & $\mathrm{p}$ & 0,229 & 0,318 \\
\hline & $\mathrm{n}$ & 99 & 99 \\
\hline
\end{tabular}

There is no statistically significant correlation between age, total working period and general job satisfaction score, internal factors score and external factors score $(p>0,05)$. These results are not statistically significant but it is seen that as the age and total working period raise, general job satisfaction, internal factors score and external factors score decrease.

\section{DISCUSSION}

General job satisfaction score and external factors score are significantly higher in the ones working in FHCs as primary health staff compared to the ones working in PHCs (Table 3). General job satisfaction scores of the participants are at "sufficient" level. In the study by Tekin (Tekin et al., 2014: 135139) carried out by FHS, job satisfaction levels were found at medium level. This may be because FHS have clear job descriptions and fixed working places while PHS are sent to different places to work temporarily, they are supported to work in the units other than their own and their inappropriate physical working conditions.

In FHCs, Group E staffs were found to have significantly higher job satisfaction levels compared to the ones working in Group A staff. While Group A FHCs have better physical conditions and more clearly defined duty and responsibilities, Group E FHCs are just 


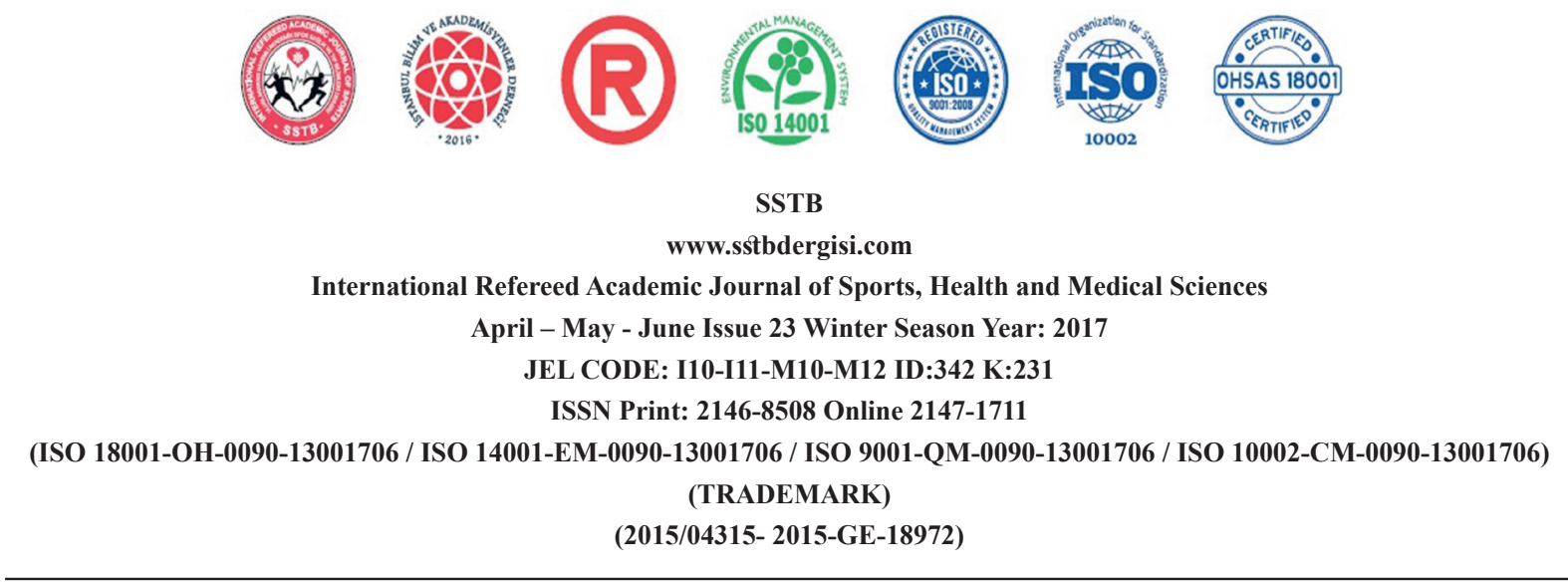

the opposite (No proper physical conditions, giving patients clinic numbers, injections, dressings, blood taking, monitoring pregnant, babies, children, women between 15-49, obesity controls, document registrations all take place in Group E FHCs. ${ }^{3}$

This can only be explained as Group E FHC staff work with a holistic approach. As a result of correlation analysis between age and total working periods of primary care nurse, midwives and FHS, a statistically significant correlation was found $(p<0.05)$. Although there was no significant correlation between age and total working period and job satisfaction scale, as age and working periods got higher, job satisfaction decreased (Table 5). In the study by Kaya et al. in Çankırı (Kaya and Bilgin, 2015: 1) it was stated that the more working periods were, the more job satisfaction was. In another study carried out with midwives in Mersin, in opposition to our study it was found out that there was a positive correlation between working periods and job satisfaction (Aydin and Akan, 2010: 1). Another study displayed similar results to our study (Tekin et al., 2014: 135-139).

There was no statistically significant correlation between total working periods and general job satisfaction scores, and between in-

3 http://ailehekimligi.gov.tr/component/content/ article/102-gorusler/2372-aile-hekimlii-uygulamayoenetmelii.html ternal factor scores and external factor scores of participants $(p>0,05)$.

\section{CONCLUSION and RECOMMENDA- TIONS}

In our study performed by 99 midwives, nurses and FHS working in primary health care institutions in Sakarya, the following conclusions were reached:

There was no statistically significant correlation between marital status, monthly incomeexpense, level of education, age, total working period and general job satisfaction, external factor scores and internal factor scores $(\mathrm{p}>0,05)$.

In terms of general job satisfaction scores, primary health care institutions, family health centers and external factor scores, there was a statistically significant difference between the state of choosing the profession willingly and the places of work at primary level $(p<0,05)$. It was found out that the staff working in FHCs and Group E FHCs in general have higher job satisfaction levels and also FHS have higher job satisfaction than PHS.

With respect to these results, it was recommended that;

There should be legislation and policies that would help graduate midwives and nurses choose their working units, as working areas are the factors influencing job satisfaction, 


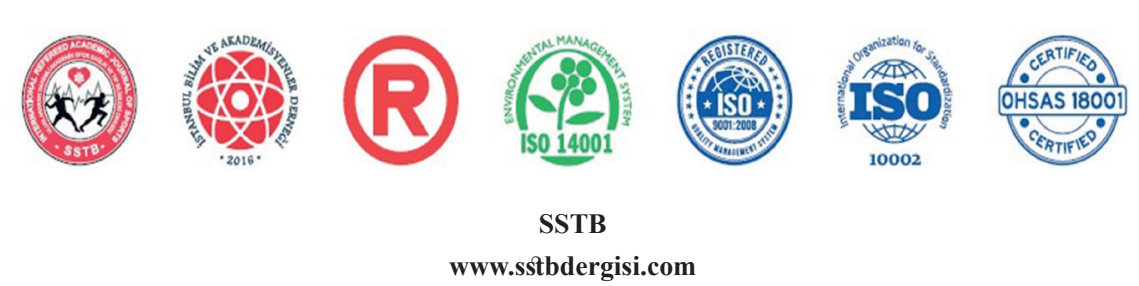

International Refereed Academic Journal of Sports, Health and Medical Sciences

April - May - June Issue 23 Winter Season Year: 2017

JEL CODE: I10-I11-M10-M12 ID:342 K:231

ISSN Print: 2146-8508 Online 2147-1711

(ISO 18001-OH-0090-13001706 / ISO 14001-EM-0090-13001706 / ISO 9001-QM-0090-13001706 / ISO 10002-CM-0090-13001706) (TRADEMARK)

(2015/04315- 2015-GE-18972)

and working conditions should be physically appropriate for the staff.

The staff's physiological, psychological and social needs should be supported.

Secondments for nurses and midwives working in PHCs should be omitted, their working hours should be arranged, their safety should be guaranteed and more efficient and satisfactory work performance of health workers should be ensured.

This study is suggested as a source of data for other similar studies aiming to evaluate the factors affecting job satisfaction levels of staff.

\section{REFERENCES}

DUXBURY, M.L., ARMSTRONG, G.D., DREW, D.J., HENLI, S.J., (1984). Head nurse leadership style with staff nurse burnout and job satisfaction in neonatal intensive care unit. Nursing Research, 33(2): 97-101

DURMUŞ, S., GÜNAY, O., (2007). Hemşirelerde iş doyumu ve anksiyete düzeyini etkileyen faktörler. Erciyes Tıp Dergisi, 29(2). 139-146

KAHRAMAN, G., ESRA, ENGIN, E., DÜLGERLER, Ş., ÖZTÜRK, E., (2011). Yoğun bakım hemşirelerinin iş doyumları ve etkileyen faktörler. Dokuz Eylül Üni- versitesi Hemşirelik Fakültesi Elektronik Dergisi, 4(1): 12-18

AYTEKIN, A., YILMAZ, KURT, F.Y., (2014). Yenidoğan Yoğun Bakım Kliniği'nde çalışan hemşirelerde iş doyumu ve etkileyen faktörler. İzmir Dr. Behçet Uz Çocuk Hastanesi Dergisi, 4(1): 51-58

AKSU, G., ACUNER, A.M., TABAK, R.S., (2002). Sağlık Bakanlığı merkez ve taşra teşkilatı yöneticilerinin iş doyumuna yönelik bir araştırma (Ankara örneği). Ankara Üniversitesi Tip Fakultesi Mecmuası, 55(4): 271-282

ASEGID A., BELACHEW, T., YIMAM, E, (2014). Factors influencing job satisfaction and anticipated turnover among nurses in sidama zone public health facilities, south Ethiopia. Nursing Research and Practice, 2014: 1-26. Doi: http://dx.doi. org/10.1155/2014/909768

ÇETIN, H., AYGEN, ZETTER, Z., TAŞ, S., ÇAYLAK, M., (2013). İş doyumu ve çalışanların demografik özellikleri arasındaki ilişkilerin belirlenmesi: Antalya Atatürk Devlet Hastanesi Örneği. Akdeniz İktisadi ve İdari Bilimler Fakültesi Dergisi, (26): 145-163

ERBIL, N., BOSTAN, Ö., (2004). Ebe ve hemşirelerde iş doyumu, benlik saygısı ve etkileyen faktörler. Atatürk Üniversitesi 


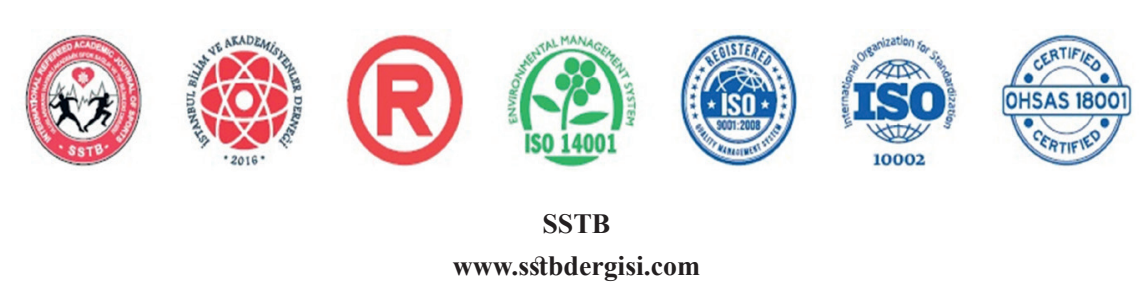

International Refereed Academic Journal of Sports, Health and Medical Sciences

April - May - June Issue 23 Winter Season Year: 2017

JEL CODE: I10-I11-M10-M12 ID:342 K:231

ISSN Print: 2146-8508 Online 2147-1711

(ISO 18001-OH-0090-13001706 / ISO 14001-EM-0090-13001706 / ISO 9001-QM-0090-13001706 / ISO 10002-CM-0090-13001706) (TRADEMARK)

(2015/04315- 2015-GE-18972)

Hemşirelik Yüksekokulu Dergisi, 7(3): $1-11$

KAYA, N.T., BILGIN, S., (2015). Çankırı il merkezinde birinci basamak sağlık kuruluşlarında çalışan ebe ve hemşirelerde iş doyumu düzeyi ve etkileyen faktörlerin değerlendirilmesi. Hacettepe University Faculty of Health Sciences, 1(1): 1-24

AYDIN, M., AKAN, N., (2010). Mersin Büyükşehir Belediyesi sınırları içinde çalışan ebelerin mesleki doyumu. Mersin Üniversitesi Sağlık Bilimleri Dergisi, $3(1)$

HAMPTON, G.M.., PETERSON, R.T., (2012). Job satisfaction of certified nurse midwives: an examination. Administrative Issues Journal: Education, Practice, and Research, 2(2): 112-126

SENBOUNSOU, KHAMLUB, S., ORRASHID, M.H., SARKER, M.A.B., HIROSAWA, T., OUTAVONG, P., et. al., (2013). Job satisfaction of health-care workers at health centers in Vientiane Capital and Bolikhamsai Province, Lao PDR. Nagoya Journal of Medical Science, 75(3-4): 233-241

TEKIN, Ç., BOZKIR, Ç., SAZAK, Y., ÖZER, A., (2014). Malatya il merkezinde çalışan aile hekimleri ile aile sağ $\operatorname{l̆g}_{1}$ elemanlarının, aile hekimliği uygulaması hakkındaki görüşleri, iş doyumu düzeyleri ve etkileyen faktörler. Firat Tıp Dergisi, 19(3): 135-139

ERAT, Ş., KORKMAZ, M., ÇIMEN, M., YAHYAOĞLU, G., (2011). Hemşirelerin iş yaşam kalitesinin motivasyona etkisi. Uluslararasi Hakemli Akademik Spor Sağlik ve Tıp Bilimleri Dergisi, 1(1): 4877

KORKMAZ, M., YILMAZTÜRK, A., (2011). Sağlık harcamalarının yıllara göre karşılaştırılması ve sağlık harcamalarını etkileyen faktörlerin incelenmesi. Uluslararasi Hakemli Akademik Spor Sağlik ve Tıp Bilimleri Dergisi, 1(1): 77-96

DOĞAN, N., ŞENSOY, N., MARDIN, E.E., UÇUR, I., ÖZBALCI, T., (2013). The prospects of family health center personnel about family practice. Journal of Clinical and Analytical Medicine, 4(2): 112-115

MERCANLIOĞLU, Ç., (2012). Demografik değişskenler bazinda iş tatmini boyutlarinda oluşan farkliliklar: Okmeydani Eğitim ve Araştirma Hastanesi personeline yönelik bir araştırma. Öneri Dergisi, 10(37): 121-138

BAYCAN, A., (1985). An Analysis of the several aspects of job satisfaction between 


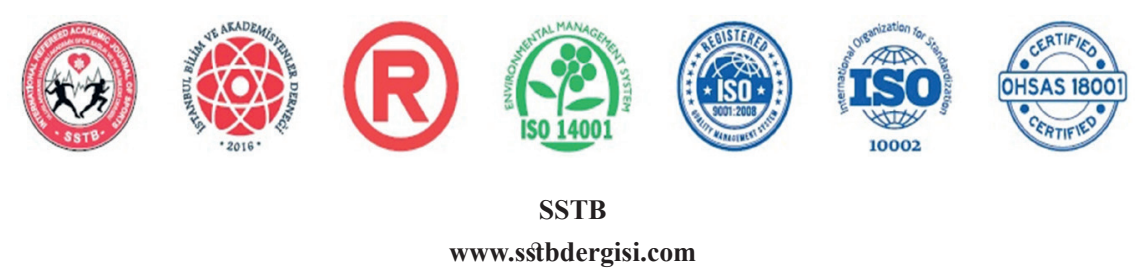

International Refereed Academic Journal of Sports, Health and Medical Sciences

April - May - June Issue 23 Winter Season Year: 2017

JEL CODE: I10-I11-M10-M12 ID:342 K:231

ISSN Print: 2146-8508 Online 2147-1711

(ISO 18001-OH-0090-13001706 / ISO 14001-EM-0090-13001706 / ISO 9001-QM-0090-13001706 / ISO 10002-CM-0090-13001706) (TRADEMARK)

(2015/04315- 2015-GE-18972)

different occupational groups. Doktora Tezi, Boğaziçi Üniversitesi Sosyal Bilimler Enstitüsü, İstanbul

DERIN, N., (2007). Devlet hastanelerinde çalışan sağlık personelinin iş doyum düzeyleri ve etkileyen faktörler. Yüksek Lisans Tezi, Eskişehir Osmangazi Üniversitesi Sağlık Bilimleri Enstitüsü, Eskişehir

\section{INTERNET SOURCES}

Http://ailehekimligi.gov.tr/toplum-salmerkezi.html accessed 12.02.2016

Http://ailehekimligi.gov.tr/component/content/article/102-gorusler/2372-aile-hekimlii-uygulama-yoenetmelii.html accessed 12.02.2016

Author's Note: This study has been presented at "3rd World Conference on Health Sciences" on 28-30 April 2016, in İzmir as an oral presentation. 